\title{
SOFTWARE INFRASTRUCTURE AS A CONTENT OF EDUCATION
}

\section{Milan KLEMENT - Jan KUBRICKÝ}

\begin{abstract}
The article treats the role of a new item in the developpement of local computer networks. It describes possible modes of optimization of the hardware and software infrastructures of a local computer network based on Microsoft technology.
\end{abstract}

Key words: network infrastructure, hardware, software, service provided by a computer network, ESX server, Microsoft.

\section{SOFTWAROVÁ INFRASTRUKTURA JAKO OBSAH VZDĚLÁVÁNÍ}

Resumé: Článek se zabývá úlohou nového prvku ve vývoji lokálních počitačových sití. Popisuje možné způsoby optimalizace hardwarové a softwarové infrastruktury lokálních počitačových sittí postavených na platformě Microsoft.

Klíčová slova: sitová infrastruktura, hardware, software, služby počitačové sítě, ESX server, Microsoft.

\section{1 Úvod}

Vzdělávání studentů učitelství informační výchovy voblasti počítačových sítí je podmíněno rozsáhlým souborem znalostí a dovedností, jejichž osvojení samotné výuce $\mathrm{v}$ této problematice předcházejí. Z tohoto důvodu můžeme vzdělávání $\mathrm{v}$ oblasti počítačových sítí právem označit $\mathrm{v}$ rámci aplikované informatiky nadřazené, protože v sobě zahrnuje soubory znalostí a dovedností dřive nabytých a obohacuje je dále o další nezbytné poznatky, které se prostřednictvím př́slušné výuky mění na znalosti a dovednosti vztahující se již př́mo k počítačovým sítím. Tato skutečnost činí z této oblasti aplikované informatiky velmi náročnou a zároveň precizní záležitost.

$\mathrm{Na}$ PdF UP v Olomouci se studenti informační výchovy připravují na práci $\mathrm{s}$ počítačovými sítěmi zejména $\mathrm{v}$ předmětu Hardwarová a Softwarová konfigurace PC. $\mathrm{V}$ dalším textu se zaměříme na obsah prímo vztažený $\mathrm{k}$ problematice počítačových sítí a též modernizace, vedoucí $\mathrm{k}$ jeho inovaci v prostředí technického hlediska (hardware a software). Prozkoumáme možnosti zefektivnění provozu a údržby počítačových sítí, a uvedeme základní výhody modernizace počítačové sítě vztaženy na infrastrukturu v rámci PdF UP v Olomouci.

\section{Počítačové sítě}

Počítačové sítě doznaly $v$ průběhu času mnoho změn, od jednoduchých metalických spojení pracujících na principu pevného spojení počítačů pomocí vodivých médií, přes moderní mikrovlnné pásmo $2,4 \mathrm{GH}$, které se označuje jako standard IEEE $802.11 \mathrm{~b}$ - modulace DSSS - WiFi až po optické nebo laserové přenosové systémy.

Základem každé počítačové sítě ovšem není pouze sít'ová infrastruktura (kabeláž, přenosové pásmo apod.), ale především poskytované služby klientům a správcům této sítě $(1$, str. 110).

Existuje celá řada př́stupů a postupů jak zabezpečovat provoz služeb počítačové sítě a to především formou provozu různých operačních systémů a jejich nástaveb. Dá se zjednodušeně říci, že v současné době se prosazují především tři základní přistupy ke konstrukci a struktuře počítačových sítí a jejich služeb (2. str. 232):

a) Použití technologie LINUX poprrípadě UNIX. Použitím sítových operačních systémů postavených na těchto platformách je možné vytvořit sít'ovou infrastrukturu bez výrazných nároků na hardware. Také pořizovací ceny software, především při použití systému LINUX, jsou nižší. Nevýhodou tohoto řešení jsou vyšší nároky na konfiguraci celé struktury a také vyšší nároky na znalosti a schopnosti správce takovéto sítě.

b) Použití počítačových sítí postavených na technologii Microsoft. Pokud je použita tato technologie je nutné nasadit jeden nebo více MS Windows 2000 nebo 2003 serverů. Hardwarové nároky těchto sít'ových 
operačních systémů jsou znatelně vyšší než při použití technologie LINUX či UNIX (např́klad při požití sestavení FreeBSD apod.). Nezanedbatelný fakt je také skutečnost, že všechny systému firmy Microsoft jsou licencovány a tudíž je nutné uvolnění dostatečného objemu finančních prostředků pro nákup licencí. Nicméně je možné nakupovat licence $\mathrm{v}$ rámci programu SELECT nebo v rámci programu SELECT AE (Academic Edition) kdy cena jedné licence pro sít'ový operační systém MS Windows 2003 server Standard dosahuje částky $2235,-$ Kč. Tento licenční program mohou prostřednictvím distributorů MS software používat i školská zařízení, která jinak nemají dostatečný počet pracovních stanic pro zařazení do programu SELECT. Výhodou použití této technologie je rychlá a přehledná správa takového počítačové sítě bez nutnosti rozsáhlých znalostí v oblasti správy počítačových sítí.

c) Použití kombinace technologií LINUX a Microsoft. Jedná se o technologii virtualizace hardwarových serverů pomocí technologie VMWare ESX serveru. ESX server je softwarové řešení postavené na technologii LINUX (konkrétně sestavení RedHat), které umožňuje emulaci jednotlivých serverů, které jsou nutné pro zajištění spolehlivosti a dostupnosti služeb počítačové sítě. Jednotlivé virtuální stroje (Virtual Machine) běžící na této virtualizační vrstvě mohou být provozovány na jakékoliv technologii bez výraznějších hardwarových nároků. Výhodou tohoto řešení je především hardwarová nenáročnost a možnost flexibilního rozšiřování počtu služeb bez nutnosti zakupování nových hardwarových serverů.

\section{Typické služby počítačové sítě}

Pro potřeby dalšího textu je nutné předpokládat, že typová počítačová sít' využivá jak operačních systémů LINUX tak MS Windows. Dále předpokládejme, že se jedná o školní nebo firemní počítačovou sít o 50 - 100 klientských pracovních stanicích (nižší počet než 50 pracovních stanic je pro toto řešení neekonomický). Posledním předpokladem je fakt, že pro centrální správu hesel a př́stupů (LDAP systém) je využívána technologie MS Active Directory.
Takováto počítačová sít' by tedy měla zabezpečovat zejména tyto služby a jim příslušné servery (2. str. 58):

a) Primární radič Active Directory (infrastruktura a LDAP). Tento server zajišt'uje provoz celé doménové struktury sítě včetně bezpečnostní politiky realizované pomocí GPO (Group Policy). Dále je součástí tohoto serveru (vyplývá to $\mathrm{z}$ architektury AD) DNS server (Domain Name Server) a DHCP server.

b) Sekundární řadič Active Directory. Tento server zajištuje provoz celé doménové struktury při výpadku či úpravách primárního řadiče (zajišstovat by měl především: sekundární $\mathrm{AD}$, sekundární DNS a záložní DHCP server).

c) MS WSUS server. Jelikož drtivá většina klientských počítačů je provozována na platformě operačních systémů firmy Microsoft (Windows 98, Windows Me, Windows 2000, Windows XP a Windows Vista) je možné nasadit tuto službu pro automatické aktualizace těchto operačních systémů a software firmy Microsoft.

d) Terminálový server. Tato technologie umožňuje nasazení tzv. tenkých klienti̊ (think clients) nebo centralizování administrátorského př́stupu do počítačové sítě. Při použití technologie tenkých klientů je možné snížit náklady spojené s nákupem a provozem výpočetní techniky až o jednu polovinu.

e) Antivirový server a firewall. Pokud má počítačová sít' zajišt'ovat všechny potřebné služby s patřičnou spolehlivostí a úrovní ochrany uživatelských dat, je nutné přejít od politiky lokálních antivirových programů k centrální správě. Tento provoz v dnešní době umožňují téměř všechny antivirové programy a výrazně se tak snižují náklady na pořízení patřičného počtu licencí.

f) File nebo disk server. Sít'ové odkladiště je základním prvkem ochrany uživatelských dat, které ale zároveň zvyšují nároky na diskovou a přenosovou kapacitu celé sítě. Ve spolupráci s LDAP systémem je možné vytvořit velmi sofistikovaný systém stromové struktury, který umožňuje rychlý a efektivní přenos informací a dokumentů $\mathrm{v}$ rámci lokální, ale i mezilehlé sítě.

g) MS SQL server. Tento server zajišt'uje provoz a správu všech databázových systémů či aplikací, které jsou nutné pro 
zajištění funkčnosti firmy či školy na poli ekonomiky, managementu, knihovních služeb, DMS systémů apod.

h) MS Exchange server. Nedílnou součástí moderní komunikace je i poštovní server. Zajištění této služby mimo danou instituci (freemaily apod.) vede $\mathrm{v}$ drtivé většině př́padů $\mathrm{k}$ výpadkům při přijímání či doručování elektronické pošty.

i) Aplikační server. Většina firem či škol provozuje své webové stránky. Pro rychlo a snadnou úpravu je možné bez větších potíží provozovat vlastí www server, který je možné využívat i pro celou řadu interních informačních kanálů.

j) Testovací farmy. Pod tento typ služby můžeme zahrnout široké spektrum služeb či technologií, které jsou specifické pro danou školskou či firemní instituci.

Je samozřejmé, že výčet všech typů služeb a serverů není konečný, a jistě by se našla celá řada dalších (3, str. 521). Nicméně pokusili jsme se vyjmenovat ty nejdůležitější s ohledem na zajištění homogenity a funkčnosti informační infrastruktury, a praktičnosti užití na školách.

\section{Optimalizace Hardwarové vrstvy počítačové sítě}

Je známé pravidlo správců počítačových sítí: „co služba to hardwarový server“ (3, str. 158). Toto pravidlo má své opodstatnění, protože při výpadku serveru, na kterém je dislokováno více služeb může dojít $\mathrm{k}$ destabilizaci celé počítačové sítě a tím k zamezení poskytování jednotlivých služeb klientům.

Pokud bychom se této základní poučky přidrželi, byla by výše uvedená počítačová sít' provozována na 10 hardwarových serverech. Nicméně realita umožňuje některé služby sdružovat na jednom serveru i se zabezpečením požadované spolehlivosti a dostupnosti. Při použití tohoto pravidla je možné počet hardwarových serverů redukovat na konečné číslo 5). Přehled sloučených služeb uvádí následující tabulka:

\begin{tabular}{|c|c|c|c|c|}
\hline $\begin{array}{l}\text { Hardwarový server } \\
\text { č. }\end{array}$ & Služba 1 & Služba 2 & Služba 3 & Služba 4 \\
\hline 1 & primární $\mathrm{AD}$ & DNS1 & DHCP & \\
\hline 2 & sekundární AD & DNS2 & $\begin{array}{l}\text { záložní } \\
\text { DHCP }\end{array}$ & Antivir server \\
\hline 3 & MS SQL & WSUS & WWW server & - \\
\hline 4 & File server & Terminal server & $\longrightarrow$ & 2 \\
\hline 5 & MS Exchange & Testovací farma & 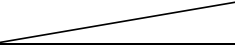 & 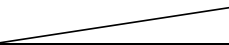 \\
\hline
\end{tabular}

Tabulka č. 1: Optimalizace rozloženi služeb na jednotlivé servery

Uvedené rozložení služeb na jednotlivé servery je možné vysledovat dle př́slušných RFC a dle doporučení Microsoft Knowledge Base.

Vychází také z autorových několikaletých zkušeností s provozem tohoto typu počítačové sítě, kdy se tato popsaná optimalizace rozložení zátěže společně s využitím popsaných nových technologií pro zajištění provozu služeb počítačové síti v praxi plně osvědčila.

Pro úplnost uvádíme, že současná optimalizovaná sít' zahrnuje celkem 152 klientských stanic (rozložených do 7 počítačových učeben a počítačových místností a 42 tenkých klientů (10 pro zaměstnance a 32 pro studenty). Systém je provozován na 8 virtualizovaných serverech a 2 fyzických terminálových serverech.
Hardwarovou vrstvu serverů tvoří 2 fyzické servery, na kterých je instalována vizualizační vrstva ESX, další 2 fyzické servery na kterých jsou provozovány terminálové servery (celková kapacita těchto serverů je 100 tenkých klientů plán rozvoje pro rok 2007). Odkladiště dat je realizováno pomocí diskového pole SAN o kapacitě 6 TB. Celková kapacita této infrastruktury je 1000 pracovních stanic a 100 tenkých klientů což představuje $100 \%$ objemu výpočetní techniky provozované $\mathrm{v}$ rámci $\mathrm{PdF}$ UP Olomouc. Tohoto objemu bude dosaženo v letech 2007 a 2008 postupným včleněním všech počítačů dislokovaných na PdF UP Olomouc do této infrastruktury. 


\section{Závěr}

Masivní rozvoj počítačových sítí vede $\mathrm{k}$ rozšiřování poskytovaných služeb a to jak klientům, tak i správcům. Objem poskytovaných služeb je závislý na hardwarové a softwarové infrastruktuře dané počítačové sítě. $\mathrm{Z}$ tohoto důvodu je nutné, aby se správci těchto sítí stále častěji zamýšleli nad optimalizací této infrastruktury, a tak se vyvarovaly některým nepř́iznivým dopadům na finanční zátěž s tímto spojenou.

Vhodným rozložením zátěže na jednotlivé servery či použitím technologie virtualizace je možné docílit vysoké spolehlivosti a dostupnosti sít'ových služeb bez nutnosti vynakládání vysokých finančních částek za hardware či software. Jedna $\mathrm{z}$ výhod, která naprosto předurčuje směr, kterým též inovovat obsah výuky.

Jak již bylo $v$ úvodu řečeno, $z$ pohledu vzdělávání učitelů je patrné, že se jedná o velmi náročnou a zároveň precizní oblast. Hledáme tak stále nové možnosti a cesty, jakými v tomto ohledu vzdělávání budoucím pedagogům zjednodušit, zefektivnit a inovovat takovým způsobem, který koresponduje $\mathrm{s}$ těmi nejpodstatnějšími výhodami přinášejícími do praxe nejvíce prosperity.

\section{Literatura}

(1) KLEMENT, M. Výpočetni technika software a hardware. 1. vyd. Olomouc : Vydavatelství UP Olomouc, 2002. ISBN 80244-4012-6.

(2) MALINA, P. Microsoft Windows Server 2003. 1. vyd. Brno : Computer Press, 2006. ISBN 80-251-1096-6.

(3) KABELOVÁ, A. Velký průvodce protokoly TCP/IP a systémem DNS. 3. aktualiz. a rozš. vyd. Praha : Computer Press, 2002. ISBN: 80-7226-675-6.

(4) AMINI, R. How to cheat at designing security for a Windows server 2003 network. Rockland : Syngress, 2006. ISBN 1-59749-2434.

(5) BERKA, M. Bezpečná počitačová sit' [CDROM]. Praha : Dashöfer, 2004. ISSN 18018033.

(6) LANGER, A. Analysis and design of information systéme. London : Springer, 2008. ISBN 978-1-84628-654-4.

(7) PRICE, B. Active Directory : optimálni postupy a řešení problémů. Brno : CP Books, 2005. ISBN 80-251-0602-0.

(8) TVRDÍKOVÁ, M. Aplikace modernich informačnich technologii $v$ řizení firmy : nástroje ke zvyšováni kvality informačnich systémů. Praha : Grada, 2008. ISBN 978-80247-2728-8.

PhDr. Milan Klement, Ph.D.

Katedra technické a informační výchovy

Pedagogická fakulta UP

Žižkovo nám. č. 5, 77140

Olomouc, ČR

Tel: 058/ 5635811

E-mail: milan.klement@upol.cz

Www pracoviště: www.kteiv.upol.cz

\author{
Mgr. Jan Kubrický \\ Katedra technické a informační výchovy \\ Pedagogická fakulta UP \\ Žižkovo nám. č. 5 \\ 77140 Olomouc, ČR \\ Tel: 058/ 5635819 \\ E-mail: jankubricky@seznam.cz \\ Www pracoviště: www.kteiv.upol.cz
}

